\title{
IMPLEMENTASI MODEL PEMBELAJARAN M-APOS DAN METODE MOORE TERMODIFIKASI UNTUK MENINGKATKAN KEMAMPUAN PEMBUKTIAN MATEMATIKA MAHASISWA
}

\author{
Abdul Aziz Saefudin ${ }^{1}$, Kintoko ${ }^{2}$ \\ ${ }^{1,2}$ Pendidikan Matematika, Universitas PGRI Yogyakarta \\ E-mail: $\underline{\text { aziz@upy.ac.id }}{ }^{1)}$,kintoko@upy.ac.id ${ }^{2)}$
}

Received 13 July 2018; Received in revised form 17 September 2018; Accepted 24 September 2018

\begin{abstract}
The study of this research is to analyze differences in the students' mathematical proving ability that follow the learning model of M-APOS learning and the conventional learning in Matrix Algebra course. This research is quasi-experiment with non-equivalent control group design. The population of this research is all students who take the Matrix Algebra the course in odd semester Academic Year 2017/2018 as many as 120 students and purposive sampling samples are as many as 79 students. The research instrument used a mathematical proving ability test. Data analysis used descriptive statistics and nonparametric statistics (Kruskal-Wallis test). The results of this study are: the average of students' mathematical proving ability that follow the M-APOS learning model and modified Moore method are significantly better than students follow conventional learning in Matrix Algebra course; there is a difference of improving the mathematical proving ability of students following the M-APOS learning model, modified Moore method, and conventional learning; the improvement in the mathematical proving ability of students following the M-APOS learning model and modified Moore method is significantly better than students who follow conventional learning in Matrix Algebra courses. The improvement of students' mathematical proving ability that follows with the M-APOS learning model is better than students who follow with the modified Moore method and conventional learning models. While the improvement of students' mathematical ability that follow with the modified Moore method is better than students who follow conventional learning.
\end{abstract}

Keywords: a modified Moore method; M-APOS learning model; mathematical proving ability

\section{PENDAHULUAN}

Ketrampilan berpikir matematika merupakan salah satu ketrampilan yang penting dikembangkan bagi mahasiswa. Alasannya, konsep matematika tersusun secara hierarkis, terstruktur, logis, dan sistematis mulai dari konsep yang paling sederhana sampai pada konsep yang paling kompleks. Ketrampilan ini penting karena materi matematika semakin sulit untuk dipelajari di tingkat perguruan tinggi, meski ketrampilan berpikir matematika, seperti kemampuan pemecahan masalah matematika juga sudah dikembangkan sejak sekolah dasar hingga sekolah menengah (Saefudin, 2012). Hal ini sejalan dengan pendapat Cornu (1991), Artigue (1998), dan Suryana (2013), yang mengemukakan bahwa pembelajaran matematika sering dinilai negatif oleh mahasiswa karena beberapa proses matematika cukup sulit dikuasai seperti penalaran, pemecahan masalah yang tidak rutin, dan membuktikan.

Dalam pembelajaran matematika di tingkat perguruan tinggi, Tall (2008) menemukan bahwa proses transisi berpikir melibatkan perubahan dari berpikir elementer ke berpikir matematis tingkat lanjut yang berbeda secara signifikan, yaitu dari mendeskripsikan ke mendefinisikan, dari meyakinkan ke membuktikan secara logika berdasarkan pada suatu definisi. Bagi mahasiswa, proses peralihan tersebut menjadi suatu permasalahan tersendiri. Salah satu penyebabnya adalah pada saat di sekolah, matematika yang mereka 
pelajari meliputi kombinasi dari representasi visual, termasuk geometri dan grafik, perhitungan dan manipulasi simbolis, sedangkan matematika di perguruan tinggi lebih menekankan pada kerangka formal sistem aksiomatik dan bukti matematika. Oleh karena itu, mahasiswa membutuhkan kemampuan berpikir yang berbeda dibandingkan saat masih di sekolah. Kemampuan yang dimaksud adalah kemampuan berpikir matematika tingkat lanjut.

Kemampuan berpikir matematika tingkat lanjut (advance mathematical thinking) merupakan kemampuan penting yang harus dikuasai oleh mahasiswa. Kemampuan tersebut meliputi representasi, abstraksi, menghubungkan representasi dan abstraksi, berpikir kreatif matematik, dan membuktikan matematik (Sumarmo, 2011). Salah satu aspek kemampuan berpikir tingkat lanjut adalah kemampuan pembuktian matematik mahasiswa. Pembuktian matematik dapat berfungsi sebagai suatu proses aktual melalui konstruksi bukti dan sebagai fase akhir (Selden \& Selden, 2003). Namun demikian, pembuktian matematis merupakan fase yang sulit bagi mahasiswa (Herlina, 2013). Hal ini disebabkan oleh beberapa hal, di antaranya mahasiswa tidak memahami suatu definisi dan teorema dengan baik, fakta ini terlihat dari tidak mampunyai mahasiswa merepresentasikan definisi tersebut. Penelitian Arnawa, dkk. (2009), Maya \& Sumarmo (2011) juga menunjukkan bahwa sebagian besar mahasiswa kesulitan untuk mengikuti perkuliahan yang membutuhkan penalaran deduktif atau kemampuan pembuktian matematik, baik kemampuan mengkonstruksi bukti maupun memvalidasi bukti. Tidak berbeda jauh, hal ini juga terjadi pada perkuliahan yang menuntut kemampuan pembuktian matematik seperti mata kuliah Aljabar Linear dan Struktur Aljabar, mahasiswa kesulitan dalam menyelesaikan permasalahan yang menuntut kemampuan pembuktian matematik (Saefudin, 2016, 2017).

Mahasiswa tersebut dikatakan mempunyai kemampuan membuktikan dalam matematika jika mempunyai dua hal, yaitu kemampuan mengkonstruksi bukti dan kemampuan memvalidasi bukti. Kemampuan mengkonstruksi bukti merupakan kemampuan mahasiswa dalam menggunakan metode-metode pembuktian, definisi, lema, dan teorema untuk menunjukkan kebenaran suatu pernyataan dalam matematika. Sedangkan kemampuan memvalidasi bukti merupakan kemampuan mahasiswa dalam usaha mengkritisi bukti yang berhubungan dengan jenis-jenis pembuktian yang sering muncul dalam matematika. Dalam melakukan kegiatan memvalidasi bukti, mahasiswa harus mampu: (1) membaca suatu pembuktian dalam matematika untuk menentukan kebenaran atau kekeliruannya dengan melihat kesesuaian antara sistem aksioma, premis, hasil-hasil matematika yang sudah ada (lema atau teorema), dengan alur penalaran deduktifnya, (2) melengkapi pembuktian (bila ditemukan ada kekeliruan), (3) membandingkan 'keefektifan' bukti yang satu dengan bukti yang lainnya (Selden \& Selden, 2003; Swam \& Ridgway, 2004, I.M. Arnawa, 2009). Oleh karena itu, untuk mengembangkan kemampuan pembuktian matematik mahasiswa perlu diterapkan pembelajaran yang berpusat pada mahasiswa (student center learning). Salah satu pembelajaran yang berpusat pada mahasiswa adalah model pembelajaran M-APOS dan metode Moore termodifikasi.

Model pembelajaran M-APOS merupakan modifikasi dari model 
pembelajaran berdasarkan teori APOS. APOS merupakan singkatan dari aksi (Action), proses (process), objek (object), dan skema (schema) (Dubinsky \& Mc. Donald, 2001). Dasar filosofis teori ini adalah konstruktivisme sosial. Ed Dubinsky merupakan pengembang teori APOS. Teori APOS adalah teori konstruktivis yang membahas tentang bagaimana belajar konsep matematika (Dubinsky \& Mc.Donal, 2003). Penerapan teori APOS dalam pembelajaran dilaksanakan dengan menggunakan siklus ADL (aktivitas, diskusi kelas, latihan soal) yang diterjemahkan dari ACE (activities, class discussion, exercises) (Saefudin, 2013). Pada tahap aktivitas, mahasiswa mengerjakan suatu tugas dengan menggunakan bantuan komputer. Kemudian, tahap diskusi kelas, mahasisiswa berdiskusi tentang hasil pengerjaan tugas yang telah diberikan. Terakhir, tahap latihan soal, mahasiswa setelah diskusi kelas diberikan latihan soal untuk dikerjakan di kelas maupun di rumah (PR). Implementasi pembelajaran teori APOS dengan berbantuan komputer pada tahap aktivitas ternyata tidak mudah dan banyak menghadapi kendala, sehingga dimodifikasi dengan memberikan lembar tugas kepada mahasiswa. Modifikasi pemberian tugas dalam kerangka pembelajaran berdasarkan teori APOS ini disebut model pembelajaran M-APOS (Nurlaelah \& Sumarmo, 2010).

Peran pemberian tugas yang diajukan dalam model M-APOS untuk memandu mahasiswa dalam mempelajari materi, mengerjakan soalsoal dan aktivitas lainnya sebelum perkuliahan tentang materi itu disampaikan. Di samping itu, pemberian tugas ini bertujuan untuk meningkatkan kegiatan belajar mahasiswa sehingga dalam pelaksanaan proses belajar mengajar mahasiswa tidak lagi pasif. Pemberian tugas ini juga memberikan kesempatan kepada mahasiswa untuk menemukan sendiri segala informasi yang diperlukan, sehingga mahasiswa memperoleh pengetahuan atau informasi tidak hanya mengandalkan dari dosen saja. Dengan demikian, mahasiswa sendiri yang menemukan informasi dan pengetahuan yang harus dipelajari dan dikuasainya.

Di samping model pembelajaran M-APOS, metode Moore termodifikasi juga dapat dijadikan salah satu alternatif dalam mengembangkan kemampuan pembuktian matematika (Saefudin, 2017). Metode Moore termodifikasi merupakan modifikasi dari metode Moore yang dikembangkan oleh R.L. Moore di University of Pennsylvania pada tahun 1911-1916, dan diajarkan di University of Texas dari tahun 1916 sampai pensiunnya pada tahun 1969 (Mahavier, May, \& Parker, 2006). Pembelajaran dengan metode Moore termodifikasi merupakan pembelajaran yang memberikan kesempatan kepada siswa untuk secara aktif terlibat dalam pembelajaran (pembelajaran dengan pendekatan tidak langsung), di mana guru atau pengajar hanya berperan sebagai motivator, fasilitator, yang mengarahkan siswanya untuk memahami suatu konsep secara mandiri dan sedikit bantuan dari pengajar sehingga pemahaman dan pembuktian matematik siswa dapat berkembang lebih baik. Oleh karena itu, penelitian ini menganalisis tentang implementasi model pembelajaran M-APOS dan metode Moore termodifikasi untuk meningkatkan kemampuan pembuktian matematika mahasiswa dalam perkuliahan Aljabar Matriks.

\section{METODE PENELITIAN}

Penelitian ini merupakan penelitian eksperimen semu (quasi 
experiment) dengan rancangan nonequivalent control group design. Populasi penelitian yakni seluruh mahasiswa yang mengambil mata kuliah Aljabar Matriks sebanyak 120 orang di Program Studi Pendidikan Matematika Universitas PGRI Yogyakarta (UPY). Pengambilan sampel dilakukan dengan menggunakan teknik sampel bertujuan (purposive sampling) yaitu 79 orang mahasiswa yang terdapat dalam dua kelas dengan satu kelas sebagai kelas eksperimen dan satu kelas sebagai kelas kontrol. Instrumen yang digunakan adalah instrumen tes kemampuan pembuktian matematika mahasiswa dalam menyelesaikan soal mata kuliah Aljabar Matriks yang telah diuji validitas dan reliabilitasnya.

Hasil validasi isi intrumen tes kemampuan pembuktian matematika menunjukkan bahwa seluruh butir dinyatakan valid oleh validator dan layak digunakan. Sementara validitas butir tes yang diukur dengan menggunakan rumus product moment menunjukkan bahwa seluruh butir dinyatakan valid ( $\mathrm{r} x y>0,3)$. Reliabilitas instrumen tes kemampuan pembuktian matematika dilakukan dengan menggunakan rumus Alpha Cronbach. Hasil analisisnya menunjukkan bahwa reliabilitas tes kemampuan pembuktian matematika (r11) adalah 0,72. Oleh karena 0,72>0,7 maka instrumen tes kemampuan pembuktian matematika adalah reliabel. Analisis data penelitian dilakukan melalui dua tahap, yaitu analisis statistik deskriptif dan analisis statistik inferensial. Jika data berdistribusi normal dan bervariansi homogen, maka untuk menguji hipotesisnya adalah dengan mengggunakan ANOVA satu jalur. Jika persyaratan analisis statistik inferensial tidak terpenuhi, maka uji hipotesis menggunakan statistika nonparametrik (uji Kruskal Wallis). Untuk menganalisis data tersebut, penelitian ini menggunakan analisis data secara manual atau berbantuan software SPSS 16.0 for windows. Untuk mengetahui seberapa besar peningkatan kemampuan pembuktian matematika mahasiswa sebelum dan setelah kegiatan pembelajaran, akan dilakukan analisis skor gain ternormalisasi.

\section{HASIL PENELITIAN DAN PEMBAHASAN}

\section{Deskripsi Hasil Kemampuan Pembuktian Matematika}

Deskripsi tes awal dan akhir kemampuan pembuktian matematika mahasiswa yang mengikuti perkuliahan dengan model pembelajaran M-APOS pada kelas eksperimen 1, metode Moore termodifikasi pada kelas eksperimen 2, dan pembelajaran konvensional pada kelas kontrol adalah sebagai berikut. 
Tabel 1. Deskripsi Hasil Tes Kemampuan Pembuktian Matematika Kelas Eksperimen 1 (M-APOS), Kelas Eksperimen 2 (Metode Moore Termodifikasi) dan Kelas Kontrol (Pembelajaran Konvensional) Sebelum dan Sesudah Perlakuan

\begin{tabular}{|c|c|c|c|c|c|c|c|c|}
\hline \multirow{2}{*}{\multicolumn{2}{|c|}{$\begin{array}{c}\text { Tes Kemampuan } \\
\text { Pembuktian } \\
\text { Matematika }\end{array}$}} & \multirow{3}{*}{$\begin{array}{l}\mathbf{N} \\
27\end{array}$} & \multicolumn{2}{|c|}{ Hasil } & \multirow{3}{*}{\begin{tabular}{r|} 
Rerata \\
44,67
\end{tabular}} & \multirow{3}{*}{$\begin{array}{c}\begin{array}{c}\text { Persen- } \\
\text { tase }\end{array} \\
44,67\end{array}$} & \multirow{3}{*}{$\begin{array}{c}\begin{array}{c}\text { Std. } \\
\text { Deviasi }\end{array} \\
19,12\end{array}$} & \multirow{3}{*}{$\begin{array}{l}\begin{array}{c}\text { Kuali- } \\
\text { fikasi }\end{array} \\
\text { Sedang }\end{array}$} \\
\hline & & & \multirow{2}{*}{\begin{tabular}{|l} 
Min \\
18,75
\end{tabular}} & \multirow{2}{*}{\begin{tabular}{c|} 
Maks \\
75
\end{tabular}} & & & & \\
\hline \multirow{3}{*}{$\begin{array}{c}\text { Sebelum } \\
\text { Perlakua } \\
\mathrm{n}(\mathrm{Tes} \\
\text { Awal } / P r \\
\text { etest })\end{array}$} & $\begin{array}{c}\text { Kelas } \\
\text { Eksperimen }\end{array}$ & & & & & & & \\
\hline & $\begin{array}{r}\text { Kelas } \\
\text { Eksperim }\end{array}$ & 27 & 18,75 & 75 & & & & \\
\hline & Kelas I & & 25 & 62,5 & & & & \\
\hline \multirow{3}{*}{$\begin{array}{c}\text { Sesudah } \\
\text { Perlakua } \\
\mathrm{n}(\mathrm{Tes} \\
\text { Akhir/Po } \\
\text { sttest })\end{array}$} & \begin{tabular}{|c|} 
Kelas \\
Eksperimen 1 \\
\end{tabular} & 27 & 62,5 & 100 & & & & Tinggi \\
\hline & $\begin{array}{r}\text { Kelas } \\
\text { Eksperim }\end{array}$ & 27 & 37,5 & 100 & & & & Tinggi \\
\hline & Kelas Kontrol & 25 & 37,5 & 100 & & Uד & 15,44 & Sedang \\
\hline
\end{tabular}

Skor ideal: 100

Berdasarkan Tabel 1 diperoleh data bahwa rerata kemampuan pembuktian matematika mahasiswa pada kelas eksperimen 1 sebelum diberikan perlakuan (treatment) adalah 44,67 dari skor ideal 100 atau 44,67\% (kualifikasi sedang) dengan standar deviasi 19,12. Sesudah diberikan perlakuan dengan model pembelajaran M-APOS, rerata kemampuan pembuktian matematika mahasiswa meningkat menjadi 93,98 dari skor ideal 100 atau 93,98\% (kualifikasi tinggi) dengan standar deviasi 10,03.

Rerata kemampuan pembuktian matematika mahasiswa pada kelas eksperimen 2 sebelum diberikan perlakuan (treatment) adalah 41,44 dari skor ideal 100 atau 41,44\% (kualifikasi sedang) dengan standar deviasi 17,35. Sesudah diberikan perlakuan dengan metode Moore termodifikasi, rerata kemampuan pembuktian matematika mahasiswa meningkat menjadi 74,54 dari skor ideal 100 atau $74,54 \%$ (kualifikasi tinggi) dengan standar deviasi 20,06.

Sementara rerata kemampuan pembuktian matematika mahasiswa dalam kelas kontrol sebelum perlakuan adalah 45,45 dari skor ideal 100 atau 45,45\% (kualifikasi sedang) dengan standar deviasi 10,16. Sesudah perlakuan dengan pembelajaran konvensional, rerata kemampuan pembuktian matematika mahasiswa menjadi 64 dari skor ideal 100 atau 64\% (kualifikasi sedang) dengan standar deviasi 15,44 .

Sebelum memperoleh
perlakuan, rerata kemampuan
pembuktian matematika pada kelas
eksperimen 1, kelas eksperimen 2,
dan kelas kontrol adalah sama. Hal
ini menunjukkan bahwa mahasiswa
pada setiap kelas terbiasa diberikan
soal-soal yang menuntut kemampuan
mengkonstruksi bukti dan
memvalidasi bukti. Selain itu, dosen


juga terbiasa menggunakan pembelajaran seperti pembelajaran berbasis masalah, pembelajaran kooperatif, dan lain sebagainya. Dengan berbagai strategi pembelajaran tersebut dan pemberian soal yang menuntut berpikir tingkat tinggi, kemampuan mahasiswa dalam mengkonstruksi bukti dan memvalidasi bukti matematika sudah dimiliki meski belum berkembang secara optimal.

Setelah memperoleh perlakuan, rerata kemampuan pembuktian matematika mahasiswa pada kelas eksperimen 1 lebih merata persebarannya dibandingkan rerata kemampuan pembuktian matematika mahasiswa pada kelas eksperimen 2 dan kelas kontrol. Sementara, rerata kemampuan pembuktian matematika kelas kontrol lebih merata dibandingkan dengan rerata kemampuan pembuktian matematika kelas eksperimen 2. Hal ini ditunjukkan dari standar deviasi kemampuan pembuktian matematika pada kelas eksperimen $1=10,03$ kurang dari standar deviasi kemampuan pembuktian matematika pada kelas kontrol $=15,44$, tetapi standar deviasi kemampuan pembuktian matematika pada kelas eksperimen 1 dan kontrol kurang dari standar deviasi kemampuan pembuktian matematika pada kelas eksperimen $2=20,06$. Artinya, penerapan model pembelajaran $\mathrm{M}$ APOS mempunyai pengaruh terhadap kemampuan pembuktian matematika mahasiswa yang lebih merata dibandingkan dengan kemampuan pembuktian matematika mahasiswa yang mengikuti pembelajaran dengan metode Moore termodifikasi dan pembelajaran konvensional pada kelas kontrol. Di samping itu, uji perbedaan rerata setelah perlakuan menunjukkan bahwa terdapat perbedaan rerata yang siginifikan kemampuan pembuktian matematika mahasiswa yang mengikuti pembelajaran dengan model pembelajaran M-APOS, metode Moore termodifikasi, dan pembelajaran konvensional. Dengan demikian, rerata kemampuan pembuktian matematika mahasiswa yang mengikuti model pembelajaran M-APOS lebih tinggi dan merata dibandingkan mahasiswa yang mengikuti pembelajaran dengan metode Moore termodifikasi dan pembelajaran konvensional. Sedangkan rerata kemampuan pembuktian matematika mahasiswa yang mengikuti pembelajaran dengan metode Moore termodifikasi lebih tinggi dibandingkan dengan mahasiswa yang mengikuti pembelajaran konvensional.

\section{Peningkatan Rerata Kemampuan} Pembuktian Matematika Mahasiswa

$$
\text { Untuk }
$$

mengetahui peningkatan kemampuan pembuktian matematika mahasiswa sebelum dan sesudah perlakuan, langkah berikutnya adalah menghitung skor gain ternormalisasi dari data sebelum dan sesudah perlakuan. Hasilnya dapat dilihat pada tabel berikut. 
Tabel 2. Deskripsi Skor Gain Ternormalisasi Kemampuan Pembuktian Matematika Mahasiswa pada Kelas Eksperimen 1, Kelas Eksperimen 2, dan Kelas Kontrol

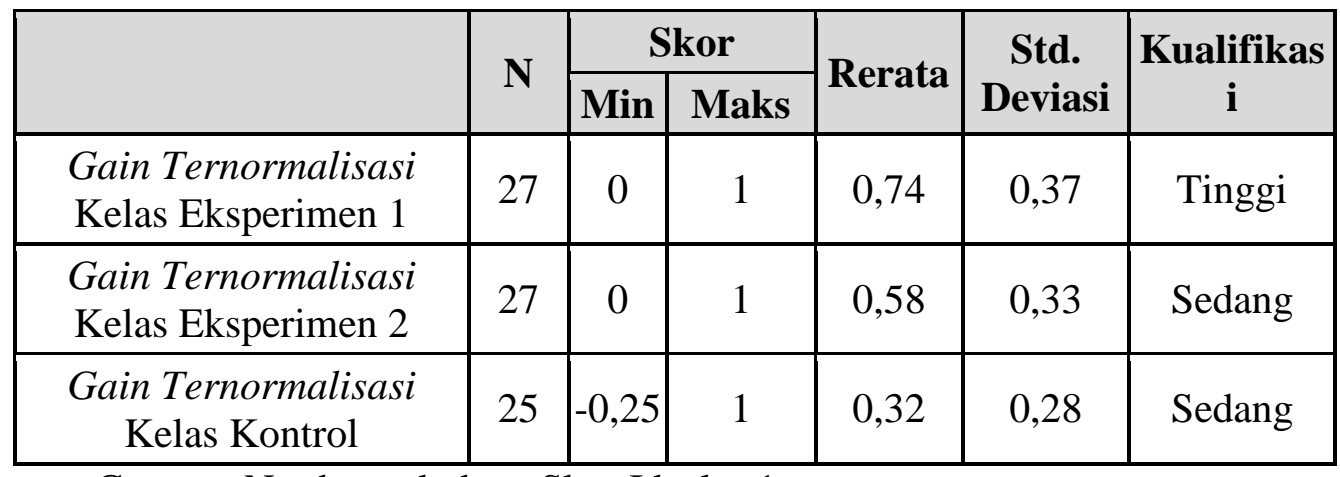

Catatan: $\mathrm{N}=$ banyak data, Skor Ideal $=1$

Berdasarkan Tabel 2, dapat dikemukakan rerata skor gain ternormalisasi kemampuan pembuktian matematika mahasiswa pada kelas eksperimen 1 yang menggunakan model pembelajaran $\mathrm{M}$ APOS adalah 0,74 (berkualifikasi tinggi) dan standar deviasi 0,37, pembelajaran pada kelas eksperimen 2 yang menggunakan metode Moore termodifikasi adalah 0,58 (berkualifikasi sedang) dan standar deviasi 0,33 , dan pada kelas kontrol yang menggunakan pembelajaran konvensional adalah 0,32 (berkualifikasi sedang) dan standar deviasi 0,28 . Perbandingan rerata skor gain ternormalisasi kemampuan pembuktian matematika mahasiswa secara keseluruhan antara model pembelajaran M-APOS, metode Moore termodifikasi, dan pembelajaran konvensional adalah rerata $0,74>0,58>0,32$, sedangkan standar deviasinya adalah $0,37>0,33$ $>0,28$. Hal ini menunjukkan bahwa peningkatan kemampuan pembuktian matematika mahasiswa yang menggunakan model pembelajaran MAPOS lebih baik daripada peningkatan kemampuan pembuktian matematika mahasiswa yang mengikuti pembelajaran dengan metode Moore termodifikasi dan pembelajaran konvensional. Selanjutnya, untuk mengetahui signifikansi peningkatan kemampuan pembuktian matematika mahasiswa pada kelas eksperimen 1, kelas eksperimen 2, dan kelas kontrol dapat dilakukan dengan melakukan uji perbedaaan reratanya.

Untuk menguji perbedaan rerata peningkatan kemampuan pembuktian matematika mahasiswa, maka diperlukan menguji skor gain ternormalisasi kemampuan pembuktian matematika mahasiswa sebelum dan sesudah perlakuan. Sebelum dilakukan pengujian skor gain ternormalisasi, terlebih dahulu dilakukan uji prasyarat analisis yakni uji normalitas dan uji homogenitas.

Uji normalitas skor gain ternormalisasi dilakukan dengan menggunakan uji statistik Kolmogorov-Smirnov karena data $\leq$ 30. Berdasarkan hasil uji data gain ternormalisasi dengan KolmogorovSmirnov pada kelas eksperimen 1 diperoleh statistik 0,274 dengan $\mathrm{df}=$ 27 dan signifikansi $(p)=0,00<0,05$ (data tidak berdistribusi normal), kelas eksperimen 2 diperoleh statisik 0,158 dengan $\mathrm{df}=25$ dan signifikansi $(p)=$ $0,082>0,05$ (data berdistribusi normal) dan kelas kontrol diperoleh statistik 1,55 dengan $\mathrm{df}=25$ dan signifikansi $(p)=0,125>0,05$ (data berdistribusi normal). Nilai 
signifikansi skor gain ternormalisasi kelas eksperimen 1 menunjukkan bahwa data berasal dari populasi yang tidak berdistribusi normal karena nilai signifikansi kurang dari $0,05(0,00<$ $0,05)$, sedangkan kelas eksperimen 2 dan kelas kontrol menunjukkan bahwa data berasal dari populasi yang berdistribusi normal karena nilai signifikansi lebih dari $0,05(0,082>$ 0,05 dan $0,125>0,05$ ).

Uji homogenitas digunakan untuk memperlihatkan bahwa tiga kelompok data sampel berasal dari populasi yang memiliki variansi sama. Uji homogenitas dalam penelitian ini menggunakan taraf signifikansi 0,05 $(5 \%)$. Uji homogenitas skor gain ternormalisasi kemampuan pembuktian matematika mahasiswa kelas eksperimen 1, kelas eksperimen 2, dan kelas kontrol dengan uji Levine sebesar 1,597 dengan signifikansi $(p)$ $=0,209>0,05$ (data homogen). Hasil yang diperoleh menunjukkan bahwa data skor gain ternormalisasi sampel berasal dari populasi yang bervariansi sama.

Uji hipotesis untuk menjawab rumusan masalah yang kedua dilakukan untuk membuktikan bahwa terdapat peningkatan kemampuan pembuktian matematika mahasiswa pada kelas eksperimen 1, eksperimen 2 , secara signifikan dibandingkan dengan kelas kontrol. Uji hipotesis ini dilakukan dengan menggunakan data skor gain ternormalisasi kelas eksperimen 1, eksperimen 2, dan kelas kontrol pada uji Kruskal-Wallis, karena data berasal dari populasi yang tidak berdistribusi normal, meski sampel berasal dari populasi yang memiliki variansi sama (homogen). Berdasarkan perhitungan uji perbedaan rerata dengan uji Kruskal-
Wallis diperoleh statistik $=16,923$ dan nilai signifikansi yaitu 0,00 . Hasil tersebut menunjukkan bahwa $0,00<$ 0,05 sehingga $\mathrm{H} 0$ ditolak. Artinya, terdapat perbedaan secara signifikan peningkatan kemampuan pembuktian matematika mahasiswa yang pembelajarannya menggunakan model pembelajaran M-APOS, metode Moore termodifikasi, dan pembelajaran konvensional. Dengan melihat rerata skor gain ternormalisasi pada Tabel 2, maka peningkatan kemampuan pembuktian matematika mahasiswa yang mengikuti pembelajaran dengan model pembelajaran M-APOS lebih baik daripada mahasiswa yang mengikuti pembelajaran dengan metode Moore termodifikasi dan model pembelajaran konvensional. Namun, peningkatan kemampuan pembuktian matematika mahasiswa yang mengikuti pembelajaran dengan metode Moore termodifikasi lebih baik daripada mahasiswa yang mengikuti pembelajaran konvensional.

Secara garis besar, perbandingan rerata skor pretest, skor posttest, dan skor gain ternormalisasi kemampuan pembuktian matematika mahasiswa yang mengikuti model pembelajaran M-APOS, metode Moore termodifikasi, dan pembelajaran konvensional dapat dilihat pada grafik berikut.

Secara garis besar, perbandingan rerata skor pretest, skor posttest, dan skor gain ternormalisasi kemampuan pembuktian matematika mahasiswa yang mengikuti model pembelajaran M-APOS, metode Moore termodifikasi dan pembelajaran konvensional dapat dilihat pada grafik berikut. 
ISSN 2089-8703 (Print) Vol. 7, No. 2 (2018) 253-265

ISSN 2442-5419 (Online)

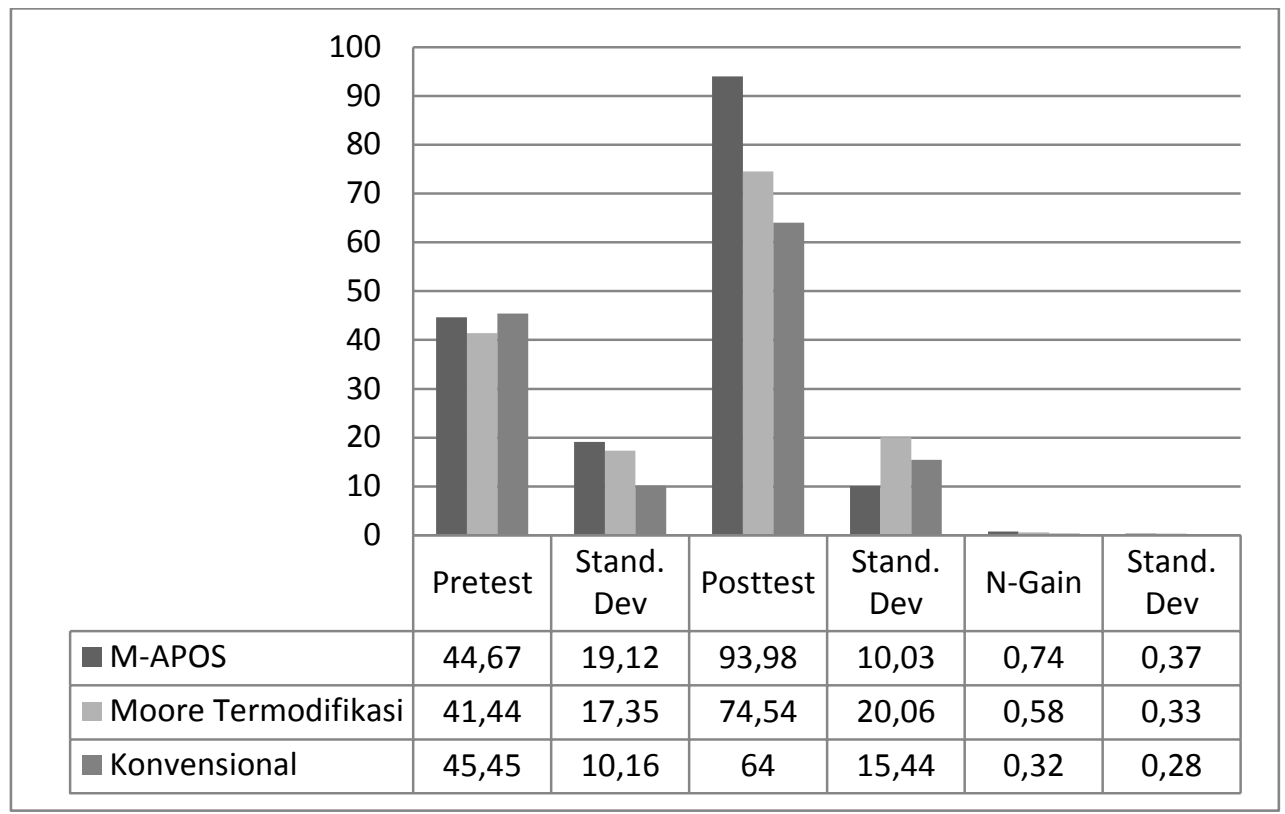

Gambar 1. Perbandingan rerata skor pretest, skor posttest, dan skor gain ternormalisasi kemampuan pembuktian matematika mahasiswa

Dalam penelitian ini, pembelajaran Aljabar Matriks dengan model pembelajaran $\mathrm{M}$ APOS dimaksudkan untuk mengembangkan kemampuan berpikir mahasiswa, khususnya kemampuan pembuktian matematika. Kemampuan pembuktian matematika mahasiswa berkembang lebih baik dengan model pembelajaran M-APOS daripada metode Moore termodifikasi dan pembelajaran konvensional. Namun, metode Moore termodifikasi dapat mengembangkan kemampuan pembuktian matematika mahasiwa dibandingkan pembelajaran konvensional. Salah satu alasannya, model pembelajaran M-APOS dan metode Moore termodifikasi mempunyai karakteristik pembelajarannya berpusat kepada mahasiswa (student centered learning) sehingga meningkatkan aktivitas belajar mahasiswa.

Model pembelajaran MAPOS diiringi dengan menggunakan siklus ADL (aktivitas, diskusi, dan latihan). Siklus aktivitas dimodifikasi dengan memberikan aktivitas pengganti penggunaan komputer yaitu berupa pendahuluan pemberian tugas untuk mempelajari materi berikutnya. Tugas tersebut disusun dalam suatu lembar kerja. Pada lembar kerja tersebut disusun serangkaian perintah yang memiliki peran yang sama seperti aktivitas yang dilakukan pada aktivitas di laboratorium komputer (Nurlelah dan Sumarmo, 2009). Pemberian tugas ini dilakukan pada akhir pembelajaran. Pada penelitian ini, tugas kelompok mahasiswa adalah pembuktian matematika pada perkuliahan Aljabar Matriks dalam bentuk lembar diskusi. Pemberian tugas tersebut akan memberikan peluang kepada mahasiswa untuk menggali segala pengetahuan atau informasi yang diperlukan dari berbagai sumber. Alhasil, mahasiswa menemukan sendiri validasi bukti matematika yang 
diberikan meskipun belum sepenuhnya memadai.

Dengan belajar secara kelompok, hasil penyelesaian tugas yang diperoleh mahasiswa dimungkinkan akan tertanam lama dan bermakna dalam ingatan mahasiswa. Selain itu, pemberian tugas ini juga dapat membantu mahasiswa dalam mempersiapkan proses perkuliahan pada pertemuan berikutnya. Dengan demikian, mahasiswa tidak hanya pasif menunggu penjelasan ilmu pengetahuan dosen di dalam kelas, tetapi mahasiswa menjadi lebih aktif dan menumbuhkan kemandirian belajar mahasiswa, termasuk di dalamnya meningkatkan inisiatif dan sikap tanggungjawab atas penyelesaian suatu tugas.

Setelah mahasiswa menyelesaikan lembar kerja diskusi, berikutnya perwakilan kelompok mahasiswa diminta untuk menyampaikan hasil diskusinya. Dalam tahap ini, mahasiswa dapat belajar sekaligus menggali ilmu pengetahuan yang ada dalam kegiatan diskusi. Sementara dosen bertindak sebagai fasilitator pembelajaran untuk mengarahkan diskusi menuju pemahaman konsep yang benar. Jika terdapat kebuntuan dalam diskusi, dosen dapat memberikan pertanyaan-pertanyaan yang mendorong mahasiswa menemukan solusi yang diharapkan. Setelah tahap diskusi dilakukan, langkah berikutnya dosen memberikan latihan-latihan soal yang bertujuan untuk memantapkan dan menerapkan konsep-konsep yang telah dikonstruksi dalam menyelesaikan soal. \begin{tabular}{lrr}
\multicolumn{2}{c}{ Keberhasilan } & model \\
pembelajaran & M-APOS & dalam \\
meningkatkan & kemampuan
\end{tabular} pembuktian matematika mahasiswa dalam penelitian ini sejalan dengan penelitian I.M. Arnawa, dkk. (2009) yang meneliti tentang kemampuan mahasiswa dalam memvalidasi bukti dalam perkuliahan Struktur Aljabar dengan menerapkan salah satu pembelajaran yang berpusat pada mahasiswa (student centered learning) yakni pembelajaran berdasarkan teori APOS. Kesimpulan yang diperoleh dalam penelitiannya bahwa mahasiswa yang memperoleh pembelajaran Struktur Aljabar berdasar teori APOS mempunyai kemampuan memvalidasi bukti lebih baik secara signifikan dibandingkan dengan mahasiswa yang memperoleh pembelajaran konvensional.

Di sisi lain, pembelajaran dengan metode Moore termodifikasi juga dapat meningkatkan kemampuan pembuktian matematika mahasiswa. Keberhasilan metode Moore termodifikasi dalam meningkatkan kemampuan pembuktian matematika mahasiswa dalam penelitian ini sejalan dengan pendapat Mahavier, May, dan Parker (2006) yang menyatakan bahwa metode Moore merupakan metode pedagogi yang efektif, dalam membangkitkan minat siswa untuk bertanya, bereksplorasi, menemukan (discover), dan mengembangkan matematika dengan kemampuannya sendiri. Hal ini juga sejalan dengan penelitian Maya dan Sumarmo (2011) serta penelitian Saefudin (2016, 2017), yang menunjukkan bahwa pembelajaran dengan metode 
Moore termodifikasi dapat meningkatkan kemampuan pembuktian matematika mahasiswa.

Berdasarkan ulasan tersebut, dapat diambil kesimpulan bahwa dosen sebaiknya menerapkan pembelajaran yang berpusat pada mahasiswa (student centered learning) dalam perkuliahan yang mengkaji permasalahan pembuktian. Pembelajaran yang dimaksud seperti pembelajaran dengan metode Moore (termodifikasi), pembelajaran berdasarkan teori APOS, M-APOS atau pembelajaran yang berpusat pada mahasiswa lainnya.

\section{KESIMPULAN DAN SARAN}

Berdasarkan deskripsi dan pembahasan terhadap hasil penelitian, dapat disimpulkan bahwa: rerata kemampuan pembuktian matematika mahasiswa yang mengikuti model pembelajaran $\mathrm{M}$ APOS dan metode Moore termodifikasi lebih tinggi secara signifikan daripada mahasiswa yang mengikuti pembelajaran konvensional dalam perkuliahan Aljabar Matriks; dan terdapat perbedaan peningkatan kemampuan pembuktian matematika mahasiswa yang mengikuti model pembelajaran M-APOS, metode Moore termodifikasi, dan pembelajaran konvensional. Rerata peningkatan kemampuan pembuktian matematika mahasiswa yang mengikuti model pembelajaran M-APOS dan metode Moore termodifikasi lebih baik secara signifikan daripada mahasiswa yang mengikuti pembelajaran konvensional dalam perkuliahan Aljabar Matriks. Peningkatan kemampuan pembuktian matematika mahasiswa yang mengikuti pembelajaran dengan model pembelajaran M-APOS lebih baik daripada mahasiswa yang mengikuti pembelajaran dengan metode Moore termodifikasi dan model pembelajaran konvensional. Sementara peningkatan kemampuan pembuktian matematika mahasiswa yang mengikuti pembelajaran dengan metode Moore termodifikasi lebih baik daripada mahasiswa yang mengikuti pembelajaran konvensional.

Saran penelitian ini adalah model pembelajaran M-APOS dan metode Moore termodifikasi dapat digunakan untuk mengembangkan kemampuan pembuktian matematika mahasiswa sehingga dosen dapat menggunakan pembelajaran ini sebagai salah satu alternatif dalam perkuliahan Aljabar Matriks. Selain itu, dosen dapat menggunakan pembelajaran yang berpusat pada mahasiswa (student centered learning) dalam perkuliahan, termasuk melakukan penelitian lanjutan dengan pembelajaran tersebut, terutama pembelajaran yang menekankan pada permasalahan pembuktian, karena dapat mengembangkan ketrampilan berpikir matematik dan kemandirian belajar mahasiswa.

\section{UCAPAN TERIMAKASIH}

Ucapan terima kasih peneliti sampaikan kepada LPPM UPY yang telah memberikan dana hibah penelitian dosen/kompetisi tahun akademik 2017/2018. 


\section{DAFTAR PUSTAKA}

Arnawa, I.M. dkk. (2009). Mengembangkan Kemampuan Mahasiswa dalam Memvalidasi Bukti pada Aljabar Abstrak melalui Pembelajaran Berdasarkan Teori APOS. Jurnal Matematika dan Sains, 14(2): 7682.

Artigue, M. (1998). Teacher Training as a Key Issue for The Integration of Computer Technologies. In: Tinsley D., Johnson D.C. (eds) Information and Communications Technologies in School Mathematics (pp. 121-129). IFIP - The International Federation for Information Processing. Springer, Boston, MA.

Cornu, B. (1991). Limits, In Tall, D. (Ed.) Advanced mathematical thinking (pp. 153 - 166). The Netherlands: Kluwer Academic Publishers.

Dubinsky, E. \& McDonal, M. (2003). "Using a Theory of Learning in College Mathematics Courses, Journal Kent State University, pg. 11.

Dubinsky, E. \& McDonal, M. (2001). "APOS: A Constructivist Theory of Learning in Undergraduate Mathematics Education Research". Dalam D. Holton (ed.). The Teaching and Learning of Mathematics at University Level. Dordrecht: Kluwer Academic Publishers.

Herlina, E. (2013). Meningkatkan Advanced Mathemathical Thinking Mahasiswa dengan Menggunakan Pendekatan APOS, Prosiding Seminar Nasional Matematika dan Pendidikan Matematika STKIP Siliwangi Bandung, Volume 1, Tahun 2013. ISSN 977-2338831, hal. 315-327.
Mahavier, W.T., May, E.L., \& Parker, G.E. (2006). A Quick-Start Guide To The Moore Method. [Online]. Tersedia:

http://www.discovery.utexas.edu/r $\underline{\mathrm{lm} / \text { reference/quick_start-3.pdf [10 }}$ April 2018].

Maya, R; Sumarmo, U. (2011). Mathematical Understanding and Proving Abilities: Experiment with Undergraduate Student by Using Modified Moore Learning Approach, Indoms. J.M.E 2 (2): 231-250.

Nurlaelah, E. \& Sumarmo, U. (2010). Implementasi Model Pembelajaran APOS dan Modifikasi-APOS (M-APOS) pada Mata Kuliah Struktur Aljabar (Makalah). Bandung: FMIPA UPI.

Saefudin, A. A. (2012). Pengembangan Kemampuan Berpikir Kreatif Siswa dalam Pembelajaran Matematika dengan Pendekatan Pendidikan Matematika Realistik Indonesia (PMRI). Jurnal AlBidāyah, 4 (1): 37-48.

Saefudin, A. A. (2013). Pengembangan Bahan Ajar Mata Kuliah Aljabar Linear Elementer (ALE) Berdasarkan Model Pembelajaran APOS untuk Menumbuhkembangkan Daya Matematika dan Disposisi Matematika. Laporan Penelitian. Yogyakarta: Universitas PGRI Yogyakarta.

Saefudin, A. A. (2016). Implementasi Pembelajaran dengan Metode Moore Termodifikasi untuk Meningkatkan Kemampuan Pembuktian Matematik dan Kemandirian Belajar Mahasiswa pada Mata Kuliah Aljabar Linear. Laporan Penelitian. Yogyakarta: Universitas PGRI Yogyakarta. 
ISSN 2089-8703 (Print) Vol. 7, No. 2 (2018) 253-265

ISSN 2442-5419 (Online)

Saefudin, A. A. (2017). Implementasi Pembelajaran dengan Metode Moore Termodifikasi untuk Meningkatkan Kemampuan Pembuktian Matematik Mahasiswa pada Mata Kuliah Struktur Aljabar. Jurnal Aksioma, 6 (3): $\quad$ DOI: $\underline{10.24127 / a j p m . v 6 i 3.1058}$

Selden, A; Selden, J. (2003).

Validations of Proof Considered as Texts: Can Undergraduates tell Whether an Argument proves a Theorem?, Journal for Research in Mathematics Education, 34(1): 4-36.

Sumarmo, U. (2011). Advanced Mathematical Thinking and Habit of Mind Mahasiswa. Bahan Ajar Mata Kuliah Kajian dan Isu Pendidikan Matematika. Bandung: Pascasarjana UPI dan STKIP Siliwangi Bandung.

Suryana, A. (2013). Penerapan Model Pembelajaran PACE dalam Meningkatkan Advanced Mathematical Thinking, Prosiding Seminar Nasional Matematika dan Pendidikan Matematika STKIP Siliwangi Bandung, Volume 1, Tahun 2013. ISSN 977-2338831, hal. 272-279.

Swam, M. and J. Ridgway. (2004). Convincing and Proving Task, [online], tersedia: http://www.flaguide.org/extra/do wnload/cat/math/convincing/conv ince.pdf. [25 Februari 2018].

Tall, D. (2008). The transition to formal thinking in mathematics. Mathematics Education Research Journal, 20(2), 5-2. 